\title{
The Development of Adobe Animate Application in the Form of a Digital Learning of Wayang Golek Reyog Ponorogo to Introduce the Characters of Patriotism in Early Childhood in the Era of Covid-19 Pandemic
}

\author{
Sulton $^{1}$, Prihma Sinta Utami ${ }^{2}$, Betty Yulia Wulansari ${ }^{3}$ \\ ${ }^{1,2,3}$ Faculty of Teacher Training, Universitas Muhammadiyah Ponorogo, Indonesia \\ *Corresponding author.Email: sulton@umpo.ac.id' ${ }^{1}$,prihmasinta@gmail.com², bettyyulia22@gmail.com ${ }^{3}$
}

\begin{abstract}
The era of the industrial revolution 4.0 is a challenge for people to be able to compete according to their fields, especially in literacy and the learning process independently. The current Covid-19 pandemic has certainly changed many aspects of life, one of which is clearly felt for the world of education is the process of implementing learning. As it is known, the learning process is not only focused on delivering material alone, but character values need to be strengthened as a strategy to strengthen the identity of the nation's generation. Early childhood is the golden age where children are still easy to receive all knowledge and learning appropriately, including understanding the character of patriotism through the local culture of their area. This article aimed to introduce one of the digital learning application developments for wayang golek Reyog Ponorogo in introducing the character of patriotism in early childhood, especially in the current Covid-19 pandemic era. The method used was Research and Development with the research subjects of early childhood teachers in Ponorogo City. From the results of the analysis of the development of digital learning for wayang golek Reyog Ponorogo, the following results were found: 1) making digital learning applications using Adobe Animate CC 2019 application is presented through 4 main views, namely, a glimpse of the history of wayang golek Reyog Ponorogo, an introduction to figures of wayang golek Reyog Ponorogo, Bantarangin Version of Reyog Ponorogo Legend, and wayang golek Reyog Ponorogo manuscript; 2) making and implementing video trailers of the digital learning application of wayang golek Reyog Ponorogo for ECE (Early Childhood Education) teachers in the city of Ponorogo; 3) conducting a limited trial of 5 ECE teachers in Ponorogo City using laptop; 4) evaluating the implementation of limited trial results with the results of $80 \%$ of the digital learning application of wayang golek Reyog Ponorogo that can be accepted by ECE students in Ponorogo City with the help of the coordination of teachers and parents of students through laptop application during the Covid-19 pandemic.
\end{abstract}

Keywords: Learning Applications, Character Values of Patriotism, Early Childhood, Covid-19 Era Learning

\section{INTRODUCTION}

The challenge of the global world today is to prepare a generation that is responsive to the rapid development of technology. The Indonesian people are currently facing the challenges of the 4.0 industrial revolution era which is becoming a trend in the industrial world that combines automation technology with cyber technology. Susetyo emphasized that this is what makes many lifestyle changes or millennials live in the digital ecosystem [1]. One of the visible changes of this era is the emergence of a digital culture which has become a major part of millennial life. This has an impact on all sources of information being very open and easily accessible. Furthermore, the habit of searching for information has become a culture. This is what makes it easier for the negative influences on society, especially for children to accept new things outright, to enter. Even more extreme, nowadays there are more and more cases that lead to acts of radicalism among the younger generations concerning about the loss of the ideological principles of Pancasila and the character of patriotism which is implanted as the national identity.

Pancasila becomes the highest guideline in Indonesia or is said to be Staatsfundamentalnorm, an ideology that is universal. This means that Pancasila can be accepted by society and can last forever. When a person interprets Pancasila as a guide in his life, then the character of patriotism will be increasingly formed in him. As stated by Birondo [2], the character of patriotism itself appears when a person has special affection for his own country, a sense of personal identification with his own country, a special attention to the welfare of the country, and of course the willingness to sacrifice for his country. .

The younger generation is one of the main components in supporting the upholding of the character of patriotism. This starts from an early age when they must 
know and love about their country and nation. Early childhood is said to be the golden age in a stage of human development, which means that the golden age in introducing all learning values, morals, and cognitive understanding. From an early age, it is very important to introduce the principles of national character life as a provision for their future life.

One way to get to know and love the state and nation of Indonesia is through the introduction of local culture and existing local wisdoms. Knowing the local culture and its ins and outs will bring a sense of pride in a person so that they can form a sense of nationalism itself in the form of patriotism.

Seeing the current facts that the world is experiencing an extraordinary pandemic, namely the presence of the corona virus. This pandemic period requires changes in all aspects of life, one of which is the learning process. The learning process has certainly undergone drastic changes starting from the level of elementary to Higher Education. The current fact is that humans are faced with digital literacy which requires them to continue to develop following technological developments. This is apperently seen from the development of children today who are already much interested in educational things but are packaged in a modern way. The current learning process must also follow the flow of the development of the 4.0 industrial revolution so that it continues to be able to prepare potential future generations of the nation who are adaptive about changing times. In this study, the researchers saw that it was time for the world of education at the Early Childhood Education (ECE) level to be able to combine virtual-based learning with direct learning. This aimed to educate children in accordance with the development of the era through positive content which indirectly can instill a positive understanding as well. Not only in alleviating learning problems at the ECE level during a pandemic, but also creativity to package learning with interesting media can be developed at any time according to the needs and demands of the times.

This research is a development research aimed at the learning process at the ECE level, especially during the current pandemic. The form of the development of this research is to develop a learning application in the form of a digital application about the introduction of wayang golek Reyog Ponorogo. The study of existing material content is directed at the introduction of the history of Reyog Ponorogo, the introduction of the Reyog Ponorogo characters, as well as the development of stories about wayang golek Reyog Ponorogo. The development of this application is collaborated with the Adobe Animate CC 2019 application which is manifested in the form of a digital learning application that is easily accessible to teachers. It is hoped that the learning application created here will be able to be used by ECE teachers to introduce the character of patriotism from an early age in a way that attracts attention and is easily accepted by children through the wisdom of the indigenous culture around where they live. Furthermore, it is hoped that through the development of this learning application it can be one of the new breakthroughs in the development of national technology for the world of education, especially in the current pandemic era.

\section{METHODS}

The Adobe Animate CC 2019 application development in the form of a digital learning application for Wayang Golek Reyog Ponorogo used the type of Research and Development. According to Borg and Gall, R\&D is an industry-based development model that finds something that can be used to design new products and procedures which are then systematically carried out in field trials, evaluations, and refined to find specific criteria for effectiveness, quality, and standards [3]. According to Borg and Gall, the Research and Development procedure has two main objectives, namely developing the product and testing the feasibility of the product [3]. In the first stage in product development, two stages of development were carried out. Firstly, a digital learning application with the Adobe Animate CC 2019 application was developed, and then a trailer video of the digital learning application of wayang golek Reyog Ponorogo which was prepared for the advanced stage of research, namely Trial, was developed. In the second stage, it was continued with limited trial activities for 5 ECE teachers in Ponorogo City using a laptop. Lastly, the evaluation stage of the implementation of the limited trial results was carried out.

\section{RESULTS AND DISCUSSION}

\subsection{Wayang Golek Reyog Ponorogo Learning Application Development with Adobe Animate CC 2019}

This wayang golek Reyog Ponorogo learning application is the result of the development of wayang golek Reyog Ponorogo prototype, the development of wayang golek Reyog Ponorogo story script which is finally packaged in a learning application in the form of digital media which is very easy to apply to (Early Childhood Education) ECE teachers and ECE children. As we know that today we face the challenges of the $21^{\text {st }}$ century, especially in the focus of the learning process. UNESCO through the journal of "The International Commission on Education for the Twenty First Century" emphasizes sustainable education (for life) which is based on four pillars of the learning process, namely: Learning to know (learning activities carried out to master knowledge), Learning to do (activities learning to know skills), Learning to be (learning to develop themselves), and Learning to live together (learning to live in society) [4]. Looking at the four pillars of education that need to be developed in today's globalized world, teachers are highly required to be able to master and apply Information and Communication Technology in the learning process. 
The development of wayang golek Reyog Ponorogo learning application in Early Childhood is one of the researchers' strategies to bridge or as a solution in the learning process for ECE teachers, especially in Ponorogo Regency in the current Covid-19 pandemic era. In the process of developing this learning application, the researchers focus on the ease of access as well as the meaning that is easily accepted by young children. The process or development is as follows:

\subsubsection{Learning Application Contents}

In this learning application, wayang golek Reyog Ponorogo consists of 4 contents of the application that discusses at a glance about wayang golek Reyog Ponorogo, Reyog Ponorogo Legend, and wayang golek Reyog Ponorogo manuscript. The contents are as follows:

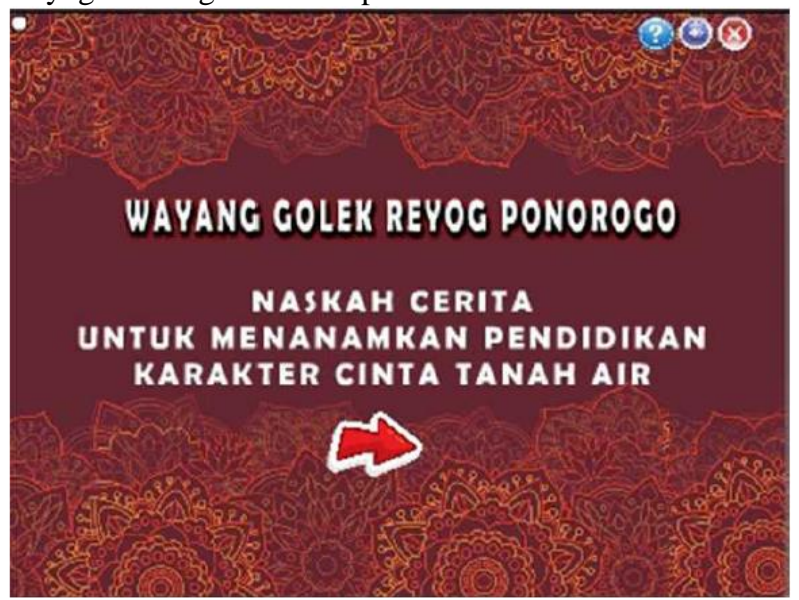

Figure 1. Preliminary View of Wayang Golek Reyog Ponorogo Learning Application

The picture above is the initial display of the learning application about wayang golek Reyog Ponorogo. In the display shown by the Adobe Animate CC 2019 application, it can make it easier for teachers or students to continue learning at the next stage automatically. When the teachers or students click the arrow symbol to the right, the screen will automatically move to the next page. The display presented in this Learning Application is deliberately packaged for Early Childhood targets so that the content displayed does not use too many abstract symbols which are not all understood by children equivalent to ECE or Kindergarten. Furthermore, the next display is a page that displays the contents of the main points that can be selected by the teachers or students. Here is the display:

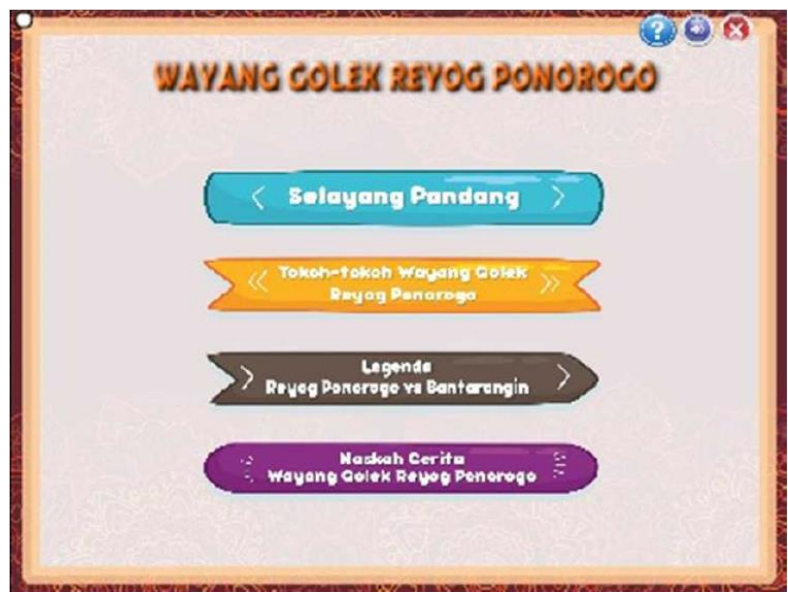

Figure 2. Contents of Wayang Golek Reyog Ponorogo Learning Application

The picture above is a display of the contents of wayang golek Reyog Ponorogo Learning Application which consists of 4 selected content that can be selected by the teachers or students as desired. The 4 content displays discuss the first about wayang golek Reyog Ponorogo. This display explains the history of the discovery or creation of wayang golek Reyog Ponorogo itself. In brief, this presentation explains that wayang golek Reyog Ponorogo is a new art resulting from acculturation in Indonesia. As it is known that Wayang Golek art is one of the arts that originated from West Java. The following is the display of the application:

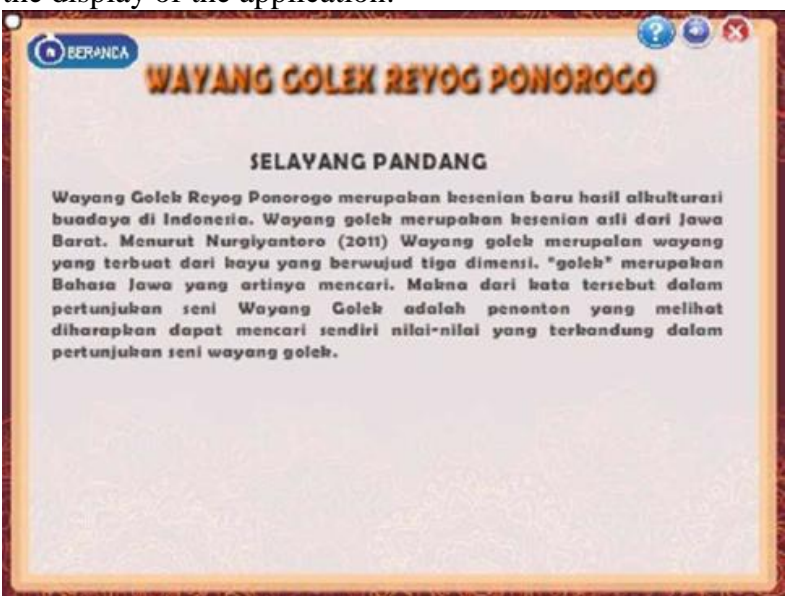

Figure 3. The Display of Learning Application Contents about Wayang Golek Reyog Ponorogo at a Glance

From the picture above, it can be seen that the purpose of this overview is to provide information to readers about the origin or of wayang golek Reyog Ponorogo. The authors here emphasize that wayang golek Reyog Ponorogo is a new art that combines two arts from West Java, namely Wayang Golek, and the arts from East Java, namely Reyog Ponorogo. It is hoped that the targeted students, ECE students, will understand the diversity of cultures that exist in multicultural Indonesia. 
Furthermore, in the content display of this Learning Application, it is also shown wayang golek Reyog Ponorogo figures. In this display, the authors aimed to provide information to readers or application users about the appearance of Wayang Golek Reyog Ponorogo characters who have not been recognized in the environment so far. As previously explained, this research created new findings or innovations about the acculturation of wayang golek culture itself. The application displays at this point is as follows:

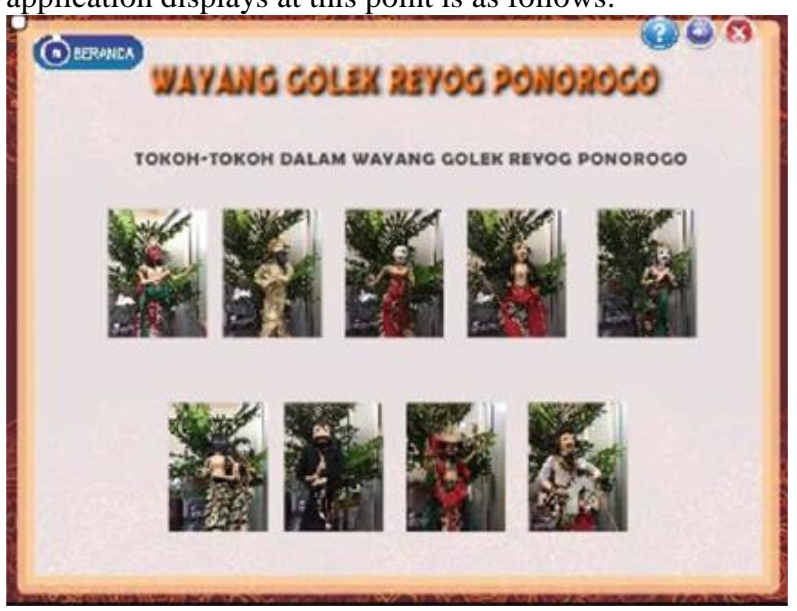

Figure 4. The display of Learning Application Contents of Characters in Wayang Golek Reyog Ponorogo

From the picture above, it can be seen that in this learning application the authors display the forms of the characters playing roles in wayang golek Reyog Ponorogo story. It is hoped that this can provide an overview and remind ECE students to get to know the characters of local figures in Ponorogo, although with other versions. As stated by Nugraheni in her research, in the current era of modernization, people's appreciation of folklore has begun to decline. On average, they tend to prefer watching television, movies, listening to songs from DVDs, cellphones, rather than seeing folk stories. From this, they feel strange with folklore, and sometimes many don't even know the folklore in their area [5].

The display of the content of wayang golek Reyog Ponorogo learning application next is about the legend of Reyog Ponorogo vs Bantarangin. Trace on its history and the growing understanding in the community that the story about Reyog Ponorogo comes from several versions, including Bantarangin version. One version of Reyog Ponorogo legend which tells of the King of Bantarangin who is said to be included in the panji story. In the legend, Klana Sewandana fell in love with Dewi Songgolangit or Dewi Sekartaji who came from Kediri. In this story, the King sent Bujang Anom as the governor to propose Dewi Somggolangit. But in short Dewi Songgolangit demanded a dowry which was quite difficult and never even existed. In short, this is a story of the King Klana Sewandana's struggle to get something with hard work [6].
This legend was displayed by the authors on wayang golek Reyog Ponorogo Learning Application because it is felt that it is very necessary for the younger generation and even for children to get to know the culture in their area. The identity of a nation must always be strengthened and empowered, the cultural history of the nation does need recognition. Culture is basically a way of life that is developed and owned together and passed from one generation to the next [7].

Furthermore, in the last content, it shows the script of wayang golek Reyog Ponorogo story. The display of this story script will make it easier for teachers to tell stories to ECE students. From the description of this story script, the teachers can also develop their creativity and storytelling ability to make them more interesting in front of students. In the display of this story script, there is an affirmation of every conversation or dialogue played by the characters in wayang golek Reyog Ponorogo story. Before entering into the dialogue between characters, a prologue is given at the beginning as an overview of the story.

\subsubsection{Trailer Video of the Development of Wayang Golek Reyog Ponorogo Learning Application during Covid Pandemic 19}

The current covid-19 pandemic has certainly changed all models or types of learning carried out by teachers, from pre-school to Higher Education level. Offline or face-toface learning instantly switches to online learning. This problem is not only felt by the people of Indonesia, but almost all people in the world. Referring to several research results related to online learning, there are several interesting things to find in several countries in the world. One of the studies conducted in Indonesia which was obtained through the distribution of online questionnaires can be analyzed that online learning carried out during the Covid-19 pandemic was effective. However, the weakness here is said to be inefficient because it costs more than offline learning [8].

Interestingly, besides the positive and negative effects of online learning during the Covid-19 pandemic felt by these students, there are other positive things that were found from the teachers' points of view. One of the results of the study showed that the use of digital platforms in the learning process made teachers more innovative in packaging teaching materials and more creative in developing learning methods to attract students' interest. However, it needs to be rethought and adjusted to the abilities of each teacher, students and parents of students in readiness to provide online learning facilities [9].

In a study, the results of research in Saudi Arabia also showed a similar thing about the positive impact assessed by teachers in facing learning during the Covid-19 
pandemic. From the results of a survey of several teachers in Saudi Arabia to verify teachers preferences for various e-learning features, it showed that the majority of teachers had a positive opinion of e-learning. Furthermore, he said that there is a special focus on how the existence of elearning can overcome disruption in the education sector due to the Covid-19 pandemic [10].

Another unique fact was found in Pakistan about online learning during the Covid-19 pandemic which showed more negative effects. The results of the survey conducted showed that online learning could not produce the desired results in underdeveloped countries such as Pakistan, where most students were unable to access the internet due to technical and monetary problems [11].

Referring to several perspectives that view the impact of online learning during the Covid-19 pandemic, there were positive and negative impacts behind this phenomenon. However, referring to the regulation of the Minister of Education and Culture of the Republic of Indonesia regarding Circular Number 4 of 2020 concerning Implementation of Education Policies in an Emergency Period for the Spread of Corona Virus Disease (Covid-19). The learning system is directed to be carried out using a personal computer (PC) or laptop that is connected to an internet network connection. In this policy, educators can learn together at the same time using groups on social media such as the WhatsApp (WA) application, Telegram, Instagram, Zoon applications or other media [12].

In this research activity, the researchers also attempted to implement learning in accordance with the rules conveyed by the Minister of Education and Culture of the Republic of Indonesia. One strategy is the packaging of explanatory material about wayang golek Reyog Ponorogo story with the form of a learning application. But here the researchers realize that not all ECE teachers can use the application. As seen from the results of research conducted in Kendari on ECE teachers, it was found that out of 95 respondents who were ECE educators, there were still ECE educators who did not carry out learning in the midst of the Covid-19 pandemic. There were still many ECE educators who were not proficient in using online learning applications \{13]. Therefore, for these reasons, a strategy was made to make a trailer video using wayang golek Reyog Ponorogo Learning Application.

The development of the trailer video for wayang golek Reyog Ponorogo Learning Application was carried out in several stages so that it was very easy for the teacher to understand before applying it to students or conveyed to the students' parents at home. In the first stage, instructions were given by the research team about how wayang golek Reyog Ponorogo Learning Application functions, in general. Furthermore, in the second stage, the instruction was given on the functions of each tool in each content displayed in the application. The next stage is an example of using the Learning Application from the beginning to the ending to make it easier for teachers to implement later. The development of this trailer video can then be saved as an .MP4 file that can be played via a cellphone or laptop.

\subsection{Limited Testing of Wayang Golek Reyog Ponorogo Learning Application Development}

In the development of wayang golek Reyog Ponorogo Learning Application after going through the process of development and validation of media experts, the results of limited trials were then carried out on ECE teachers in Ponorogo Regency, totaling 5 ECE teachers. In this product trial activity, the teachers were given direct training by the research team, as for the stages in the limited trial of wayang golek Reyog Ponorogo Learning Application product as follows: First stage, the teachers were given general direction on the intent, purpose and function of using wayang golek Reyog Ponorogo Learning Application in the ECE learning process during the Covid19 pandemic; Second stage, the teachers were given a file of wayang golek Reyog Ponorogo Learning Application which was distributed in one flashdisk to be copied on the respective teacher's laptop; The third stage, the team assisted the teachers in installing wayang golek Reyog Ponorogo Learning Application on the teacher's laptop; The fourth stage, the team delivered a trailer video for using wayang golek Reyog Ponorogo application, which had previously been copied together in 1 flashdisk of the application; The fifth stage, the teachers were asked to practice using the application and to ask questions about things, steps or symbols that were not understood yet; The sixth stage, the teachers selected in the limited trial practiced the application directly to early childhood education students using the home visit method in several of the closest study groups.

Direct practical activities carried out by 5 ECE teachers who were selected in the limited trial, were carried out using the home visit method of study groups with different numbers of students. The participants including 5 ECE teachers come from different schools so it is hoped that the information conveying on the use of this learning application can be used evenly. The number of students who took part in the limited trial activity implementation of Wayang Golek Reyog Ponorogo Learning Application was 18 students. From the results of the analysis that has been carried out through practice in the field, the result obtained was $80 \%$ of target students have understood and accepted the teacher's explanation of wayang golek Reyog Ponorogo Learning Application and were enthusiastic in using the application. The $80 \%$ percentage was obtained from $65 \%$ of the students were very enthusiastic about participating in learning activities from beginning to end, $10 \%$ of students were enthusiastic about participating but did not fully participate in learning until it was finished, and $5 \%$ of students understood what the teacher explained but were less enthusiastic in the activity of asking questions and having discussions with the teacher. The 
activities carried out by the teachers were also accompanied by the parents of the students so that when parents wanted to practice independently at home they could be given files from the teacher.

\subsection{Evaluation Results of Limited Test Development of Wayang Golek Reyog Ponorogo Learning Application Development}

From the results of limited trials conducted in the field, there were several interesting things that could be used as an evaluation in improving the product of wayang golek Reyog Ponorogo Learning Application. The results of the evaluation that were found from the results of trials in the field were as follows: 1) In general, the teachers responded very well to the existence of wayang golek Reyog Ponorogo Learning Application as a new alternative for learning in early childhood, especially in the current pandemic period; 2) There needs to be an additional backsound not only at the beginning of opening the application, but each application item or content with special music about wayang golek Reyog Ponorogo so that students can focus from beginning to end; 3) It is necessary to add content to the quiz symbols so that students do not feel bored listening to the teachers' explanation; 4) In the future, the application is expected to be packaged into the cellphone system so that it is easy to install, especially through the playstore so that parents can also easily use it outside of teacher guidance.

Based on the input given by the teachers and the responses of parents in the field, the researchers used them as a foothold for the researchers to improve wayang golek Reyog Ponorogo Learning Application before it was carried out in a broad trial and could be used by all ECE teachers in Ponorogo Regency. The improvements made by the team include: 1) Added music backsound to the application by adding national songs to foster a sense or character of patriotism in students, additional national songs include Indonesia Raya, Independence Day song 17 Agustus 1945, and Tanah Air song; 2) Added points or symbols for the quiz or question and answer students in which are short questions from the characters and the story of wayang golek Reyog Ponorogo.

\section{CONCLUSION}

The results of the development of wayang golek Reyog Ponorogo Learning Application is still not optimal. There are several shortcomings and need further improvement. Even though in the implementation in the field, most students were very enthusiastic and understood the teachers' explanation about the story and history of wayang golek Reyog Ponorogo. The result obtained was that $80 \%$ of students had accepted and understood the implementation of wayang golek Reyog Ponorogo Learning Application with a description of the percentage of $65 \%$ students was enthusiastic to follow the learning from the beginning to the ending, $10 \%$ of students were enthusiastic but did not fully follow the learning until the ending, and $5 \%$ of students understood what the teachers explained but they were less enthusiastic in questioning and discussion activities with the teachers. There were several factors that become obstacles in implementing wayang golek Reyog Ponorogo Learning Application in the field. One of these obstacles is the lack of time for teachers to provide explanations to students because it is limited in the current Covid-19 pandemic. This makes the teacher less optimal in implementing and developing the creativity of telling stories longer in the field. From the existing activities, it can be concluded that the development of wayang golek Reyog Ponorogo Learning Application can be an alternative or solution for ECE teachers, especially in Ponorogo Regency, to implement learning during the Covid-19 pandemic. In addition, through wayang golek Reyog Ponorogo Learning Application, it can be a way to reintroduce students, especially early childhood, about the taste or character of patriotism which they can get from the introduction of stories, history and the accompaniment of national songs in this application.

\section{ACKNOWLEDGMENT}

This article is one of a series of research outputs in the Multiyears Higher Education Superior Research 2019-2020 which is fully funded by Ristekdikti.

\section{REFERENCES}

[1] Susetyo, B. A. (2019). Reorientasi Profesionalisme Pendidikan dalam Menghadapi Tantangan Revolusi Industri 4.0.

[2] Birondo N. (2020) Patriotism and Character. In: Sardoc M. (eds) Handbook of Patriotism. Spinger, Cham. https://doi.org/10.1007/978-3-319-30534-9_57-2

[3] Borg, \& Gall. (2007). An Introduction Education Research (8th ed). Upper Saddle River: Pearson Education

[4] D. Levy. (1996). Learning: the treasure within Report to UNESCO of the International Commission on Education for the Twenty-first Century. UNESCO Publishing, Paris.

[5] N.Eko Wardani, F. Kurwidaria, K. Dwi Wijayanti, D. Pangestu Said. Folklore Reog Ponorogo: Study on Value of Education for the Community, SEWORD 
FRESSH 2019, April 27, Surakarta, Indonesia. DOI 10.4108/eai.27-4-2019.2286891

[6] H. Budi Prasetya. Proceeding The International Seminar of Panji 2018 which held in Yogyakarta is a series of the 2018 Internasional panji Festival.

Published by the Cultural Office of Yogyakarta Special Region in collaboration with the directorate of Arts, the Directorate General of Culture, and Ministry of Education and Culture, ISBN 978-602-53183-5-1

[7] A. Estiastuti, A. Nurharini, K.Bektiningsih, Munisah, Cultural Heritage to Build History for Life in Social Science Learning at Primary Schools. Advances in Social Science, Education and Humanities Research, volume 382. $5^{\text {th }}$ International Conference on Education and Technology (ICET 2019). Atlantis Press

[8] A. Bahasoan, W.Ayuandiani, M.Mukhram, A.Rahmat. Effectiviness of Online Learning in Pandemic Covid-19. International Journal Of Science, Technology\&Management. ISSN: 2722-4015. http://ijstm.inarah.co.id/index.php/ijstm/about/submissi ons

[9] P. Ayu Suci Lestari, Gunawan. The Impact of Covid-19 pandemic on Learning Implementation of Primary and Secondary School Levels. Indonesian Journal of Elementary and Childhood Education, Vol.1 No.2, 2020:58-63
[10] M.Ziaul Hoq. E-Learning During the Period of Pandemic(Covid-19) in the Kongdom of Saudi Arabia: An Emperical Study. American Journal of Educational Research, 2020,Vol.8, No.7, 457-464. Available online at http://pubs.sciepub.com/education/8/7/2. Published by Science and Education Publishing. DOI: 10.12691/education-8-7-2

[11]M. Adnan, K.Anwar. Online Learning amid the Covid-19 Pandemic:Student's Perspectives. Journal of Pedagogical Sociology and Psychology, Volume 2, Issue 1, 2020. https://doi.org/10.33902/JPSP.\%202020261309

[12] L.Gede Muhammad Zainuddin Atsani. Transformasi Pembelajaran Pada Masa Pandemi Covid19. Al-Hikmah: Jurnal Studi Islam, Volume 1, Nomor 1 Tahun 2020, Terbitan Januari-Maret

[13] Nurdin, L.Ode Anhusadar. Efektivitas Pembelajaran Online Pendidik PAUD di tengah Pandemi Covid 19. Jurnal Obsesi: Jurnal Pendidikan Anak Usia Dini, Volume 5 Issue 1 (2021) Pages 686697. ISSN: 2549-8959(online). 2356-1327 (print).DOI: https://doi.org/10.31004/obsesi.v5i1.683 